\title{
5.4 Postcoronavrus formation of tourist micro-business of the region on the basis of economic security
}

\subsubsection{Theoretical aspects of the formation of postcoronavirus business} space in the regional sphere of tourism on the basis of economic security

Post-coronavirus formation in Ukraine of a modern highly efficient and competitive tourist complex requires solving a number of tasks, namely: improving the regulatory framework and system of public regulation of tourism, creating a modern tourism market on the basis of competition, deepening specialization and cooperation in tourism micro-companies development of various types of domestic and inbound tourism, introduction of public-private partnership mechanism, stabilization of microbusiness, modernization and transformation of regional tourism infrastructure to global standards, digital integration of Ukraine into the world tourist space, sustainable development of international cooperation in tourism to realize domestic interests business, protectionist policies to promote the creation of tourist destinations. In general, meeting the needs and demand for tourism implies the need to provide a large number of tourist services. From the point of view of economic activity, tangible and intangible tourist services are of interest to micro-business. The subjects of postcoronavirus relations in the context of tourism are the organizers and sellers (tour operators and travel agents) of the tourist product, their contractors (service providers: hotels, restaurants, carriers, operators) and buyers, both complex tourist product and separate tourist services. Thus, the business of tourism micro-enterprises is an organized work, which uses capital, recreational resources, means of production, staff, digital space for the production and sale of tourism products [187].

In the post-coronavirus business space of tourism important stages of microenterprise activity should be: adequate planning of tourist services and quality control of tourist product: preparation of tours, their methodological support, preparation of contractual documentation, work with insurance and other interested organizations (1); determination of the method of realization of a tourist product taking into account 
technological, information achievements and experience of the global tourism industry: independent realization or through other firms, commission sale through intermediaries or creation of an extensive dealer network (2); innovative ways to stimulate sales: virtual fairs, exhibitions, competitions, auctions, travel lotteries, seasonal benefits, loyalty programs for regular customers, children, promotional tours, etc. (3); selection by competencies and implementation of smart-personnel management of a travel company: calculation of the number of employees, formation of staff smart-schedule, development of digital-instructions, entrepreneurial innovative forms of remuneration, introduction of smart-regulations of micro-enterprises (4). The system of micro-enterprises in the tourism business of the region is presented in Fig. 5.4.1.

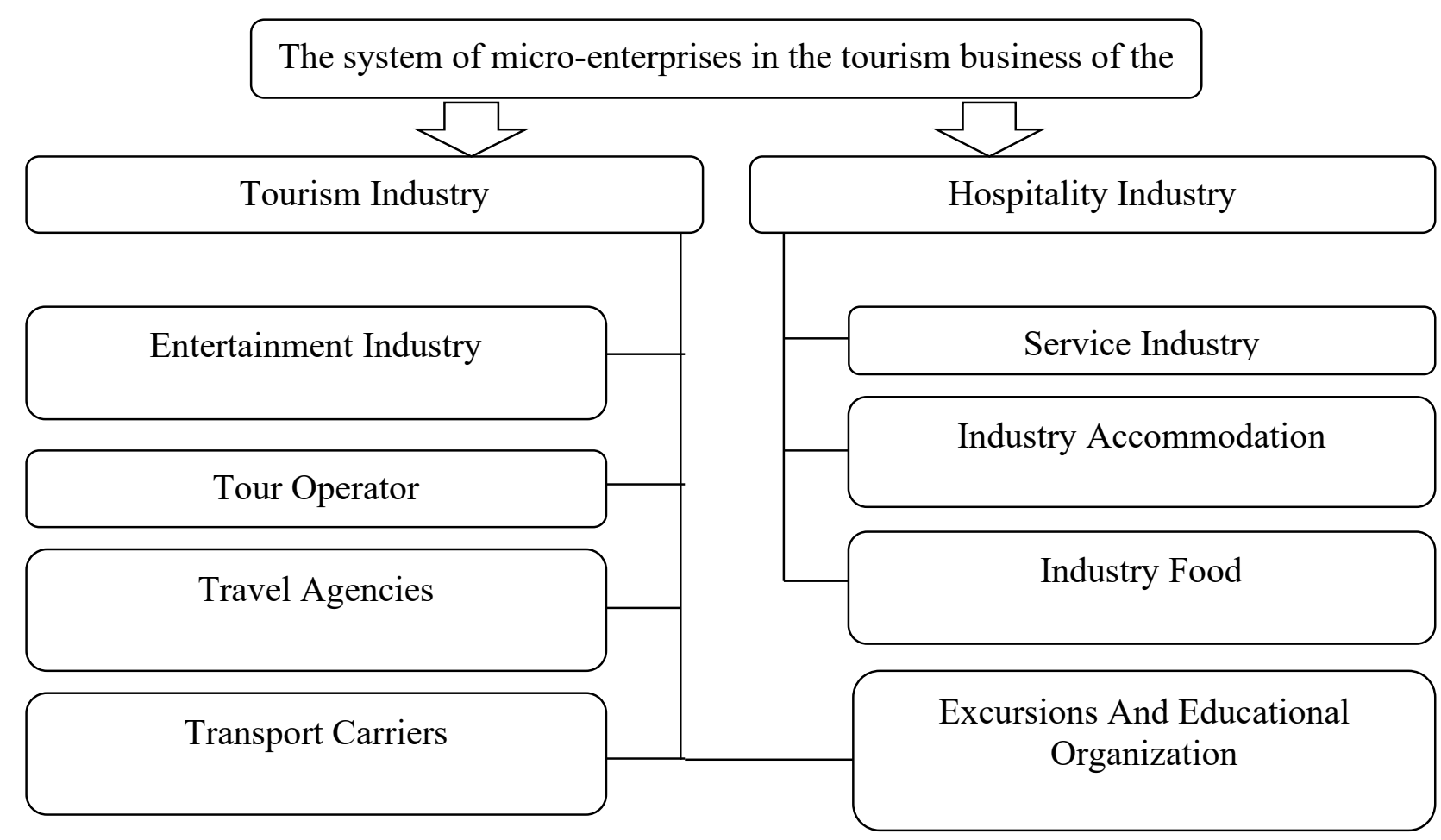

Figure 5.4.1. The system of micro-enterprises in the tourism business of the region

The transformation of the regional tourism economy to the post-coronavirus era is accompanied by the emergence of management problems that are extremely complex in content, their solution must be found by combining the efforts of leading scientific schools using the results of retrospective analysis of economic tourism systems in the conditions of COVID-19, both nationally and internationally. It should be assumed that 
the creation of a new paradigm of regional tourism economy is becoming an additional factor in its globalization. The search for a vision of development during and after the COVID-19 pandemic is gradually transforming the region's tourism sector into an effective mechanism for developing optimal steps towards a systematic vision of a comprehensive strategy, taking into account the interests of firms. However, microenterprises in the region often find themselves at a disadvantage in the market, as largescale competitors have much stronger capital, an attractive brand and strong leverage. The operators of the regional market have an additional organizational, legal and economic burden. From this point of view, the traditional approach to the use of classical tools to combat competitors is ineffective and requires immediate review, as well as the entire management system of the micro-enterprise on the specifics of the business. Therefore, it is necessary to approach the formation of post-coronavirus business space in the regional sphere of tourism on the basis of economic security.

Significant experience of scientific research on economic security has been accumulated in foreign and domestic science and practice, among which the works of D. Lambert, V. McMack, V. Muntian, G. Pasternak-Taranushchenko, V. Yarochkin should be noted. Among the authors who consider the principles of economic security, the formation of mechanisms for ensuring, assessing the economic security of the enterprise should be distinguished works: M. Bendikova, N. Vashchenko, S. Glushchenko, L. Donets, N. Kapustina, T. Kovaleva, G. Kozachenko, L. Korchevska, M. Kurkina, O. Lyashenko, E. Oleynikov, O. Razdin, V. Tambovtsev, L. Shemayev, V. Shlykov. The achievements of such well-known specialists as V. Gulyaev, I. Zinoviev, I. Zorin, V. Kvartalny, V. Kozyrev, M. Marinin, H. Savina, A. Taksanov, V. Tkach, S. Tsokhly, O. Chudnovsky are devoted to the problems of economic security management in the field of tourism. Some aspects related to the functioning and development of the world tourism industry are covered in the works of such foreign scholars as R. Barton, P. Bernecker, A. Bull, J. Ingram, C. Robinson, G. Harris, J. Holloway [188]. Despite the significant amount of research on this issue, the intensive changes in tourism caused by the factors of COVID-19, lead to the development of a comprehensive vision of post-coronavirus development in this area 
and the need to improve the management of economic security of microenterprises. Researchers from the Department of Tourism, Hotel and Restaurant Business of the National University "Zaporizhzhia Polytechnic" (leading Institute of higher education of the region) in the research work "Tourism industry of Ukraine in the period of European integration: theoretical aspect" explored the concept of "safety in tourism" modern content (Table 5.4.1).

Table 5.4.1.

Definition of "security in tourism"

\begin{tabular}{|l|l|}
\hline \multicolumn{1}{|c|}{ Authors } & \multicolumn{1}{c|}{ Contents of the concept of "safety in tourism" } \\
\hline $\begin{array}{l}\text { Zaitseva } \\
\text { V.M. }\end{array}$ & $\begin{array}{l}\text { A system of comprehensive measures that provide an adequate mechanism to } \\
\text { protect the individual from trouble and conflict during travel. }\end{array}$ \\
\hline $\begin{array}{l}\text { Tsviliy } \\
\text { S.M. }\end{array}$ & $\begin{array}{l}\text { Covers the personal and private safety of tourists, the preservation of their property } \\
\text { and care for the environment when traveling. }\end{array}$ \\
\hline $\begin{array}{l}\text { Gurova } \\
\text { D.D. }\end{array}$ & $\begin{array}{l}\text { A complex and multifaceted concept that cannot be limited to the protection of } \\
\text { tourist facilities and private security of tourists, but should be considered on many } \\
\text { levels: from national security to security of accommodation, transport, hotel, } \\
\text { recreational complexes, tourism centers. }\end{array}$ \\
\hline $\begin{array}{l}\text { Korniienko } \\
\text { O.M. }\end{array}$ & $\begin{array}{l}\text { Emphasis on the negative and dangerous factors faced by the domestic market of } \\
\text { tourist services, namely: pollution of water, air, garbage, noise, damage to wildlife. }\end{array}$ \\
\hline $\begin{array}{l}\text { Mamotenko } \\
\text { D.Yu. }\end{array}$ & $\begin{array}{l}\text { With the development of tourism, the problem of travel safety is exacerbated, and } \\
\text { since the participants of the trips face the corresponding risks, it is necessary to } \\
\text { provide the necessary measures to reduce the level of danger to tourists. }\end{array}$ \\
\hline $\begin{array}{l}\text { Vindyk } \\
\text { A.V. }\end{array}$ & $\begin{array}{l}\text { Physical and social security should be taken into account by the tourism industry, } \\
\text { whose task is to minimize and prevent threats. }\end{array}$ \\
\hline
\end{tabular}

According to table 1 concluded that within the concept of "safety in tourism" should distinguish between the safety of tourists, the safety of tourism entities and the state, the safety of the environment. Each of these concepts is multifaceted and requires specific analysis and understanding. In a general sense, the category of "security" can be interpreted as a state of protection of vital interests of all security objects (state, society, individual) from real or potential, different in origin, external and internal dangers: political, economic, military, information, environmental. According to the authors, the economic security of a tourism enterprise is a state of protection of the company's activities in the field of tourism from the negative effects of external and internal environment, as well as its ability to quickly eliminate various threats [189]. The content of this concept includes a comprehensive system of means of ensuring 
sustainable competitiveness and economic stability of the tourism enterprise, and the main purpose of its economic security system is to ensure sustainable and effective development for the realization of tourism potential in the post-coronavirus business space. It is worth noting that in the post-coronavirus period of tourism there is a need to review approaches to the formation and provision of economic security in order to maintain a stable position of enterprises in domestic and international markets, both in real and digital environment. Based on this, the structure of economic security of the tourism sector of the region will have the following components: environmental, financial, investment, social, innovation, as well as functional components. In turn, the composition of the system of economic security of the tourist micro-enterprise is logically expressed by the components: tourist, technical and economic; financial, personnel, information. The success of the enterprise in the conditions of transformation will depend on the constant monitoring of its positions, research of the strengths and weaknesses of its own business and competitors, the ability to adapt to the changing regional business space. Thus, the concept of "safety in tourism" includes: safety of tourists; safety of tourism entities and the state; safety of the environment.

At the present stage of development of the tourism economy of the regions, a large number of domestic micro-enterprises are in crisis and that is why the management faces the urgent task of forming an effective strategy for economic security of micro-companies in this area to counter external and internal threats, protect economic interests, ensuring the economic security of the micro-company in this area in order to counter external and internal threats, protect the economic interests of the enterprise, ensure stable development, increase efficiency. Depending on the size and production capacity of the enterprise, the availability of resources, scale and specifics of the problems to be solved, different approaches should be used to form a strategy to ensure its economic security [190].

In recent years, domestic tourism companies are creating special units in the structure, the main task of which is to ensure economic security. However, most of these units do not have an effectively functioning system of economic security and this aspect significantly reduces the efficiency of their business and necessitates the 
development of this strategy. At the same time, the creation of such units is a positive vector for the development of modern micro-enterprises in the region and shows the understanding of tourism market participants of the main tasks of economic security of the travel company (Fig. 5.4.2).

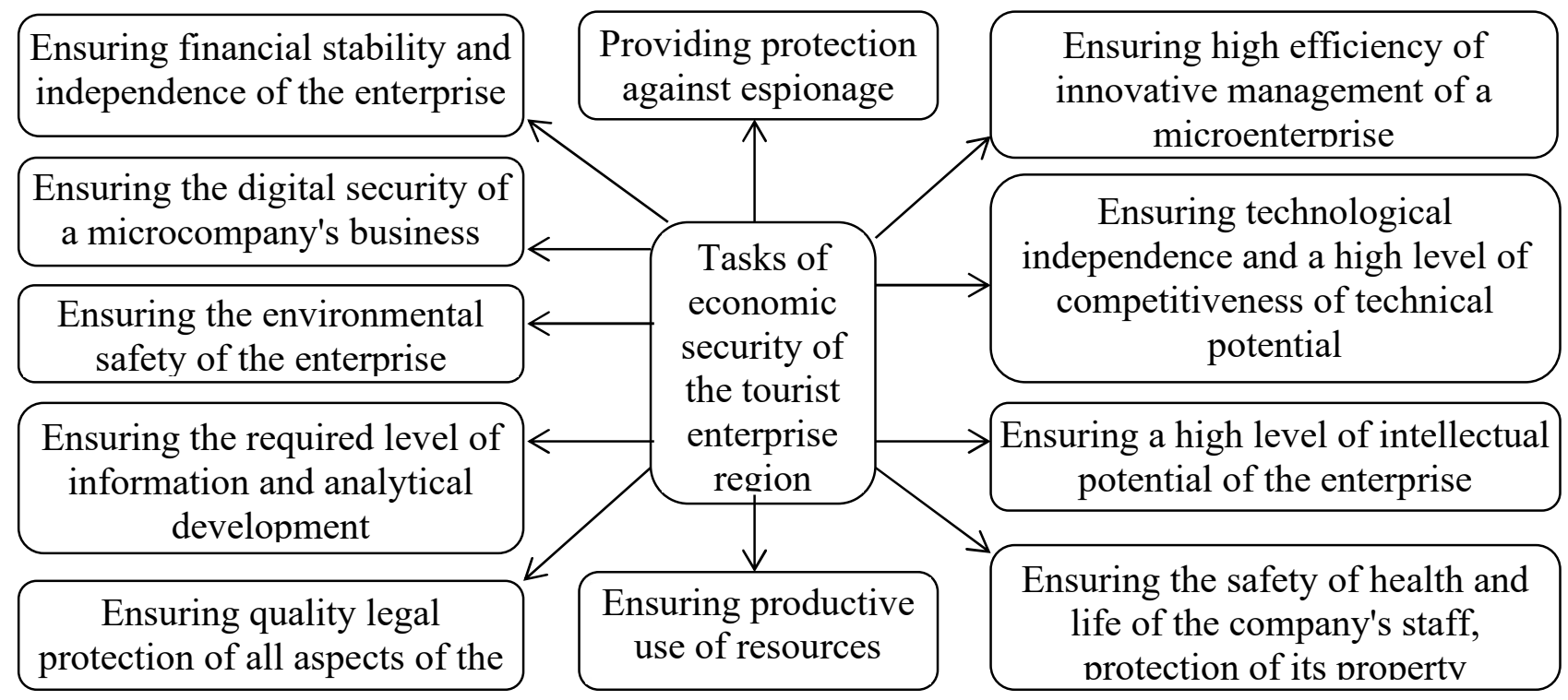

Figure 5.4.2. Problems of economic security of the tourist enterprise of the region

Given the limited budget of domestic micro-companies in the regions and the unpreparedness of a significant number of them to restructure the organizational structure, a slightly different approach to economic security can be used, the essence of which is the maximum delegation of economic security to existing units. In this case, it will not be necessary to radically reform the organizational structure, but will only need to create the position of "director of security" with the authority to lead the process of economic security of the tourist micro-enterprise. This way of solving the problem will ensure an appropriate level of economic security with minimal costs for reforming the organizational structure. However, it should be emphasized that this approach is appropriate only for innovative micro-enterprises, as it has been tested against large and medium-sized tourism companies and requires some adaptation.

It is clear that the most significant influence on the activities of micro-enterprises is exerted by the state. However, a retrospective study of the areas of state regulation of micro-business in the region showed that it aims to pursue certain interests that do 
not always coincide with the interests of enterprises. Due to the discrepancy between state interests and the interests of enterprises in a number of cases, state regulation has a negative impact on the economic security of the enterprise. Under these conditions, tourism micro-enterprises should intensify efforts to develop a post-coronavirus mechanism for economic security, which the authors propose to understand a set of managerial, economic, organizational, legal, motivational ways to harmonize the interests of the firm with the interests of the environment. The specific of the microcompany in the field of tourism business ensures a sufficient level of profit, the amount of which will be justified (at least) for the company to be in economic security [191]. As a result, the concept of creating a mechanism of economic security of a microbusiness in tourism should provide that the basis of the mechanism is the formation of a system of priority interests of the enterprise with their subsequent harmonization with the interests of the environment interacting with the micro-firm. Thus, the precondition for the post-coronavirus transformation of the concept of economic security of a microcompany is the growing negative impact of environmental factors, outdated forms and methods of state regulation of micro-business.

The method of forming the system of economic security of a micro-enterprise in the regional sphere of tourism in the post-coronavirus business space includes the following stages: studying the specifics of the micro-enterprise's business, its market segment, staffing, staff, etc. (1); analysis of external and internal threats to the economic security of the enterprise and the study of information about crisis situations, causes and ways of settlement (2); audit of available security tools, as well as analysis of their compliance with the identified threats (3); modeling of the company's postcoronavirus economic security system (4); development of a plan to eliminate the shortcomings identified during the audit (5); preparation of proposals for improving the economic security system (including the creation of a security service at the enterprise, if such did not exist, or a security system based on it, defining mechanisms for its provision and development of organizational structure of system management) and calculation of all necessary resources (6 ); planning of monthly expenses for ensuring the functioning of the system of economic security of the tourist micro-firm 
(7); approval by the management of the model of the modernized system of economic security and the budget for its maintenance (8); organizational procedures for the formation of a new system of economic security (9); evaluation of the efficiency of the formed system and vectors of its improvement (10).

The given technique of formation of system of economic safety of the tourist micro-enterprise provides realization of constant control (during and after realization of each stage), adjustment and improvement of directions of formation of system of safety for the purpose of optimum adaptation and reaction to changes in external and internal environments, the nature of risks and threats, changes in the legal field, the appearance on the market of unfair competitors, changes in the forms and methods of illegal activities, lists of confidential information and other factors. At the same time, all approaches to the development of technology for assessing the economic security of a micro-enterprise are divided into three groups: a combination of well-known proven techniques (1); independent method of assessing economic security with miscalculations of its functional components (2); comprehensive assessment of the levels of key indicators of business functioning and their ranks (3).

It should be noted that the formation of the system of economic security and the creation of entities depend on the size of the enterprise and capabilities. Practice has shown that micro-business, small firms use the services of external specialized private agencies (consulting, security, detective). Medium-sized businesses can use a combined system of economic security, relying on the capabilities and resources of their own units with partial involvement of the potential of external firms. It makes sense for large companies to create a full-fledged system of economic security with their own powerful service. It should be added that the concept of economic security of a travel micro-company involves the efficient use of resources for stable operation in the post-coronavirus business space at the operational stage and the stage of sustainable strategic development [192]. To ensure the economic security of the microcompany, it is necessary to use a set of business resources (business factors in tourism, which are used by the owners and managers of the firm to achieve goals).

Modern economic literature has a wide arsenal of methods and techniques for 
studying the economic security of micro-entrepreneurship in the region. However, given the complexity of this economic category, its dependence on economic, social, political, historical, religious, technological, psychological and other factors of society, the purpose, objectives, principles and indicators of tourism micro-entrepreneurship in the region depend on the existing system of government and are based on methodological approaches, methods, evaluation methodology that is acceptable for its evaluation. In any case, the micro-company must fully and effectively use theoretical and methodological approaches to ensure economic security in forming its own position in the post-coronavirus business space of the regional tourism sector in order to quickly restore business activity.

\subsubsection{Postcoronavirus recovery of business activity of micro-enterprises in}

\section{the hospitality sector of the region}

Under the conditions of COVID-19 factors, many issues related to the organization of business of micro-enterprises in the field of hospitality, which were previously in the status of promising and perceived by the management of microcompanies of this type quite inert. These issues include: product range and quality, additional services for guests, the company's competitiveness, consumer safety, partnerships, environmental friendliness of business, participation in targeted programs, preferential taxation, etc. It is clear that today the global and domestic tourism sector (including the regional hospitality sector) is suffering as a result of measures to counter the COVID-19 pandemic. At the same time, the current crisis situation should be considered not only as a problem, but also as an opportunity to bring the hospitality sector of Ukraine to a new level of development. The state of the regional hospitality sector and related industries and areas of regional business needs to be reviewed and adapted to the conditions of the circular economy. The basis of the transition to the structure of the regional economy of a new type is the restoration of business activity of micro-enterprises in the industry on such principles as: postcoronavirus increase in the role of micro-enterprises in the development of territories, 
destinations, regions; introduction of contemporary practices and world experience in business management of companies; implementation of public-private partnership tools; intensification of innovation and investment mechanisms at the regional level; digitalization of business processes in business. That is why the chosen direction of research is relevant and timely for companies.

The study of the state and development of the tourism industry was devoted to the works of domestic and foreign scientists, namely: Horban H., Herasimenko V., Vorotina L., Dyachenko L., Kifyak V., Kravchuk I., Lyubitseva O., Teobald U., and others. A significant contribution to the development of the hospitality industry has been made in the research of such scientists as: Azar V., Bowen J., Vindyk A., Durovich A., Karpova H., Mackenz D., Rieger A., Rogov H., Saunders D., others. Specific features of hospitality micro-company management are occasionally covered in the works of researchers, namely: Alekseeva Yu., Zaitseva V., Kuklina T., Pavlyuk K., Sklyar H., Udovychenko V., Harrod R., others. Some practical aspects of business of micro-companies of the region in the conditions of COVID-19 are considered in scientific works of Vasilichev D., Hres S., Gurova D., Zhuravlyova S., Mamotenko D. and other well-known scientists. However, in the presence of a significant number of scientific ideas today there are almost no comprehensive studies on the formation of effective approaches to identify ways to restore business activity of domestic hospitality micro-companies in the post-coronavirus economy of Ukraine [193]. That is, it is important to study the current realities of hospitality in the region and based on the study of the experience of micro-enterprises in the context of the COVID-19 pandemic to develop effective and efficient recommendations for postcoronavirus business recovery of companies of this type.

The generalization of domestic and foreign experience in determining the essential characteristics of the hospitality industry has stated that it covers business forms in the field of services related to customer service, namely: 1) types of service based on hospitality and reproducing generosity and friendliness to customers and consumers; 2) it is a set of micro-business entities (travel agencies, hotels, motels, facilities, etc.), for which the commonality lies in the complexity of physical, social, 
emotional components of the product; 3) companies in the hospitality industry (restaurants, hotels, resorts, etc.) participate in the creation of an invisible product suitable for consumption only at the time of offer to the consumer. Thus, hospitality companies are rightly identified with micro-business. COVID-19 in Ukraine has been significantly affected by micro-business enterprises in the hospitality sector in the regions, as they are the main sellers of a comprehensive product to guests.

Table 5.4.2.

Factors of negative impact on the regional hospitality sphere

\begin{tabular}{|l|l|}
\hline \multicolumn{1}{|c|}{ Factor } & \multicolumn{1}{c|}{ The essence of negative influence } \\
\hline $\begin{array}{l}\text { World economic } \\
\text { crisis }\end{array}$ & $\begin{array}{l}\text { The crisis due to the factors COVID-19 and the global economic recession, } \\
\text { which automatically affected the domestic regional hospitality sector of } \\
\text { Ukraine. }\end{array}$ \\
\hline $\begin{array}{l}\text { Military and } \\
\text { political risk }\end{array}$ & $\begin{array}{l}\text { High degree of uncertainty of future prospects of the temporarily occupied } \\
\text { Autonomous Republic of Crimea and the territory of ORDLO, which has an } \\
\text { impact on the safety of travel. }\end{array}$ \\
\hline $\begin{array}{l}\text { Recovery and } \\
\text { development plan }\end{array}$ & $\begin{array}{l}\text { Lack of a real strategy to restore business activity at the level of the state and } \\
\text { its regions, a clear plan and stages of specific economic support measures. }\end{array}$ \\
\hline $\begin{array}{l}\text { Service quality } \\
\text { standards }\end{array}$ & $\begin{array}{l}\text { Non-compliance of most domestic infrastructure facilities in the regions with } \\
\text { international standards of quality of customer service. }\end{array}$ \\
\hline $\begin{array}{l}\text { Investment } \\
\text { processes }\end{array}$ & $\begin{array}{l}\text { Inertia of the processes of investing in the restoration and development of the } \\
\text { material base of tourist facilities and the development of the transport } \\
\text { network and logistics of the regions. }\end{array}$ \\
\hline $\begin{array}{l}\text { Innovative } \\
\text { activity }\end{array}$ & $\begin{array}{l}\text { Insufficient research, research, scientific support of the industry; low } \\
\text { technical and technological level of service facilities for guest service. }\end{array}$ \\
\hline $\begin{array}{l}\text { The policy of } \\
\text { protectionism }\end{array}$ & $\begin{array}{l}\text { Lack of modern effective mechanisms to ensure business preferences at the } \\
\text { level of micro-enterprises in the region to increase their level of } \\
\text { competitiveness. }\end{array}$ \\
\hline $\begin{array}{l}\text { Business } \\
\text { regionalization }\end{array}$ & $\begin{array}{l}\text { Insufficient development of the structure of business process organization } \\
\text { and partnership in the business environment at the level of locations, } \\
\text { destinations, regions, regions. }\end{array}$ \\
\hline $\begin{array}{l}\text { Product } \\
\text { promotion }\end{array}$ & $\begin{array}{l}\text { Lack of a unified policy to promote a comprehensive product of micro- } \\
\text { enterprises in the hospitality sector of the region in the domestic and } \\
\text { international tourism markets. }\end{array}$ \\
\hline $\begin{array}{l}\text { Digitalization of } \\
\text { business }\end{array}$ & $\begin{array}{l}\text { Low level of use of digital technologies for modernization of the process of } \\
\text { complex product development and service of foreign and domestic tourists. }\end{array}$ \\
\hline
\end{tabular}

Thus, the practice of their operation in 2020-2021 confirms the large number of claims regarding violations of consumer rights and complaints from them about the insignificance of products and cases of abandonment of travel plans due to medical restrictions. Given the loss of customers, coronavirus barriers to business, and the lack 
of real assistance from public authorities, regional micro-companies suffered unjustified losses and were forced to reduce their business activity.

The study of the state of the regional hospitality sector has identified a number of factors that have a negative impact on its micro-business (Table 5.4.2).

According to table 2, seven out of ten factors are external to micro-enterprises; reduction of the negative impact of the factors "business regionalization" and "product promotion" can be achieved through the implementation of the mechanism of publicprivate partnership ; "Digitalization of business" is an internal threat to the company, which must be eliminated immediately.

It is clear that the resumption of business activity of micro-enterprises in the hospitality region in the post-coronavirus perspective should begin with a strategic analysis of their own potential and the development of an appropriate strategy taking into account the updated environmental factors. The table 3 presents the structure of micro-business of Zaporizhzhia region by type of economic activity.

According to table 3, the structure of micro-enterprises for the period 2015-2019 has not undergone significant changes. With such a division (by type of economic activity), it is advisable to group them in terms of integration into the hospitality of the region. Thus, it makes sense to include 1 group (high integration): temporary accommodation and catering; health care and social assistance; arts, sports, entertainment and recreation; (in 2019, their total share is 4.08\%). Group 2 (average integration) should include: wholesale and retail trade; repair of motor vehicles, motorcycles; transport, warehousing, postal and courier activities; information and telecommunications (34.81\%). The 3rd group (low integration) includes: agriculture, forestry and fisheries; financial and insurance activities; real estate transactions $(30.86 \%)$. That is, $69.75 \%$ of micro-enterprises in the region directly or indirectly need to resume business activity. 
Table 5.4.3.

The share of micro-enterprises of Zaporizhzhia region by types of economic activity in $2015-2019 \mathrm{in} \%$ to their total number [194]

\begin{tabular}{|l|r|r|r|r|r|}
\hline Types of activity $\backslash$ years & 2015 & 2016 & \multicolumn{1}{|c|}{2017} & 2018 & \multicolumn{1}{|c|}{2019} \\
\hline Total & 100 & 100 & 100 & 100 & 100 \\
\hline agriculture, forestry and fisheries & 18,71 & 19,97 & 20,18 & 19,39 & 18,43 \\
\hline industry & 10,44 & 10,61 & 10,75 & 11,25 & 11,69 \\
\hline construction & 7,58 & 7,13 & 7,09 & 7,18 & 7,31 \\
\hline $\begin{array}{l}\text { wholesale and retail trade; repair of motor vehicles and } \\
\text { motorcycles }\end{array}$ & 29,43 & 29,03 & 28,44 & 27,99 & 28,04 \\
\hline transport, warehousing, postal and courier activities & 3,35 & 3,15 & 3,20 & 3,32 & 3,48 \\
\hline temporary accommodation and catering & 2,41 & 2,21 & 2,34 & 2,38 & 2,43 \\
\hline information and telecommunications & 2,86 & 2,95 & 2,87 & 3,08 & 3,29 \\
\hline financial and insurance activities & 0,57 & 0,63 & 0,51 & 0,46 & 0,43 \\
\hline real estate transactions & 10,96 & 11,55 & 11,88 & 11,99 & 12,00 \\
\hline professional, scientific and technical activities & 7,20 & 6,60 & 6,34 & 6,31 & 6,11 \\
\hline $\begin{array}{l}\text { activities in the field of administrative and support } \\
\text { services }\end{array}$ & 3,21 & 3,04 & 3,32 & 3,49 & 3,57 \\
\hline education & 0,47 & 0,46 & 0,45 & 0,49 & 0,56 \\
\hline health care and social assistance & 1,22 & 1,16 & 1,14 & 1,28 & 1,18 \\
\hline arts, sports, entertainment and recreation & 0,48 & 0,45 & 0,46 & 0,43 & 0,47 \\
\hline provision of other types of services & 1,10 & 1,06 & 1,03 & 1,03 & 1,00 \\
\hline
\end{tabular}

The opinion of the owners of 50 micro-enterprises with a high degree of integration into the hospitality sector of Zaporizhzhia region regarding the prospects of rapid recovery of business activity (Google-form was filled out) was studied and based on their answers a fragment of SWOT-analysis matrix was compiled (Table 5.5.4).

Also, according to the owners of the specified number of micro-enterprises in the region, the resumption of business activity depends entirely on the realization of the internal potential of companies. From this position, recommendations have been developed for companies to choose a vector of post-coronavirus business recovery, which provides for innovative development based on a customer-oriented approach. Under the innovative development of micro-enterprises in the hospitality industry in the post-coronavirus state of the environment should be considered the trajectory of its movement, which provides external efficiency through the implementation of a system of changes of various forms, due to a combination of factors, namely: 1) new 
technologies; 2) their use in the form of new services, products and processes; 3) new markets or individual segments; 4) new organizational management structures, organizational design; 5) new approaches in management. Changes are implemented in parallel and are a product of the knowledge system [195].

Table 5.4.4.

Fragment of the matrix of SWOT-analysis (study of the prospects of post-coronavirus recovery of business activity of micro-enterprises)

\begin{tabular}{|c|c|}
\hline Strengths (S) & Weaknesses (W) \\
\hline $\begin{array}{l}\text { 1. Readiness of companies to serve guests at a } \\
\text { higher level of quality. } \\
\text { 2. Compliance with the requirements of the } \\
\text { Ministry of Health of Ukraine on health and } \\
\text { safety of institutions. } \\
\text { 3. A large number of operators providing } \\
\text { hospitality services in the region. } \\
\text { 4. Mobility and flexibility in adapting to changing } \\
\text { market and consumer requirements. } \\
\text { 5. Ease of management and control of processes } \\
\text { due to the optimal size of the company. }\end{array}$ & $\begin{array}{l}\text { 1. Low level of digitalization of microbusiness } \\
\text { and lack of a single digital platform. } \\
\text { 2. Rising prices for products, services, services } \\
\text { due to market shrinkage. } \\
\text { 3. Insufficient working capital hinders rapid } \\
\text { recovery and development. } \\
\text { 4. Lack of brand information in comparison } \\
\text { with medium and large enterprises. } \\
\text { 5. Difficulty in processing a significant amount } \\
\text { of operational marketing information. }\end{array}$ \\
\hline \begin{tabular}{|c|} 
Opportunities $(\mathrm{O})$ \\
\end{tabular} & \\
\hline $\begin{array}{l}\text { 1. The transport network of the region is developed } \\
\text { and the structure of city transport is restored. } \\
\text { 2. Growing interest of domestic tourists in the } \\
\text { organization of domestic travel. } \\
\text { 3. Respectful, polite, loyal, friendly attitude to } \\
\text { foreign tourists. } \\
\text { 4. Growth of activity on creation of information- } \\
\text { consulting hubs. } \\
\text { 5. Development guidelines are defined (Tourism } \\
\text { Development Strategy for } 2021-2027 \text { ) }\end{array}$ & $\begin{array}{l}\text { 1. Lack of a unified philosophy in the region } \\
\text { regarding the presentation of cultural heritage. } \\
\text { 2. Seasonality of demand for summer vacation } \\
\text { and weak alternative supply. } \\
\text { 3. High competition from domestic hospitality } \\
\text { spheres of other regions and cities. } \\
\text { 4. Low level of economic, financial and legal } \\
\text { and business security. } \\
\text { 5. A large number of tourist infrastructure } \\
\text { facilities need to be modernized. }\end{array}$ \\
\hline
\end{tabular}

In turn, the customer-oriented approach in the management of innovative development in the process of restoring the business activity of the microfirm involves: providing a unique service: the final product is differentiated, unique in its kind, which brings additional benefits to the consumer (1); providing a global concept of the product: the idea, design and development of goods and services must first focus on world quality standards (2); ensuring the marketing orientation of the studied processes (3); intensive primary analysis: resources should be spent on in-depth substantiation of forecast changes prior to development (3); implementation of a new product strategy: 
action plan for project implementation, list of tasks, market selection, set of properties for its positioning (4); attitude to information as a resource that is not limited by barriers and on the basis of creating a common information platform to ensure the coordination of actions of individuals with the results of micro-enterprises (5); providing crossfunctional synergy within the company's unified philosophy regarding a new product based on the organization of an information network on the vector "research production - marketing - finance - personnel" (6); ensuring the unity of the processes of updating the archive and knowledge models with other functional business processes and administration processes (7); management on the basis of a structured plan for the development of innovations: the transition from the planned positioning of the product in the minds of consumers to the plan of operational marketing in time, prices, sales channels, communications (8); support of ideas and innovations by the management of a micro-enterprise in the field of hospitality (refusal of direct intervention and interested support) (9); ensuring economic, technological, consumer, image impact of innovations (connection of all to obtain a combined effect) (10); development of a mechanism for pre-selection of innovative projects (11); control over the implementation of an innovative project, as well as timely rejection of the project when changing situational factors (12); ensuring access to resources: for success, human and financial resources should be formed for consideration as an investment, not as an expense (13); taking into account the time factor as a priority in the competitiveness of the business: rapid entry into the market with a quality product offer to the customer (14); implementation of a multi-stage procedure for evaluating future innovations (15).

It should be borne in mind that in the process of operational management it is unacceptable to combine the principles of different approaches to managing the company's innovations and focus on long-term planning and strategic management. The philosophy of post-coronavirus business, which aims to ensure the quality of sustainable consumption of services, should focus exclusively on the innovation of the organizational and economic system of the micro-enterprise [196]. Post-coronavirus management principles in a particular company must be clearly defined and 
implemented by management in procedures, regulations, organizational design, corporate culture, information system, consumer code [197].

According to the proposed approach in the post-coronavirus recovery of business activity of micro-enterprises in the hospitality sector, the mobilization of internal potential for certain components is of great importance (Table 5.4.5).

Table 5.4.5.

Mobilization of the potential of a micro-enterprise by components of the profile of its internal environment

\begin{tabular}{|l|l|}
\hline \multicolumn{1}{|c|}{ Component } & \multicolumn{1}{|c|}{ Meaningful readiness for post-coronavirus innovation } \\
\hline Production & $\begin{array}{l}\text { technology, engineering, vertical integration, procurement, quality, stocks, } \\
\text { ideas, innovations, patents, licenses, research, energy, premises, etc. }\end{array}$ \\
\hline Finances & $\begin{array}{l}\text { short- and long-term capital, flexibility of capital structure, accounting, the } \\
\text { possibility of reducing costs, taxation, the level of shadowing, etc. }\end{array}$ \\
\hline Marketing & $\begin{array}{l}\text { products, services, services, market share, promotion, sales channels, sales, } \\
\text { image, reputation, trade, communications, customers, consumers, etc. }\end{array}$ \\
\hline Personnel & $\begin{array}{l}\text { managerial staff, standard of work, morale, fluidity, competencies, } \\
\text { qualifications, motivation, incentives, income, personnel policy, etc. }\end{array}$ \\
\hline Management & $\begin{array}{l}\text { business goal, values, structure, organizational culture, corporate ethics, } \\
\text { strategic planning, synergy, internal communications, etc. }\end{array}$ \\
\hline
\end{tabular}

It is also expedient to mobilize the internal potential of the micro-company to implement a process approach in its management system based on the post-coronavirus need to ensure survival, economic security, a certain level of competitiveness, reduce the time of transformation of ideas to new market requirements, acquisition of modernized competencies by staff, strengthening positions in the field of hospitality of a particular domestic region [198].

Today, domestic micro-companies in the hospitality sector are experiencing a time of enormous financial difficulties. The paradox of the crisis period is that in the conditions of COVID-19 intensive work is carried out at the level of micro-firms and business structures to develop an effective mechanism for post-coronavirus recovery of their business activity. To ensure the competitiveness of the regional hospitality sector in the post-coronavirus space, the authors consider the adoption of emergency measures to preserve the economic potential of micro-enterprises, the development of their intellectual potential, entrepreneurial spirit and culture. Also extremely important 
is the role of informatization of business processes in the effective functioning of the micro-firm. The successful experience of transformation and adaptation to new global conditions of micro-firms from other locations, tourist destinations, regions and countries should be a useful help of micro-business. Also, the efforts of companies should be useful in developing a marketing policy to retain loyal customers of a comprehensive tourism product.

\subsubsection{Post-coronavirus marketing policy of retaining loyal consumers of hotel and restaurant product}

Changes in the political, economic, social spheres of life in Ukraine, the country's integration into the European Community, the introduction of innovative technologies determine the feasibility of improving all areas of management of hotel and restaurant companies. Global factors of the crisis, including the action of factors COVID-19 and the transformation of the tourism economy, influenced the intensification of competition, identified vectors of crisis management, intensified diversification of elements of post-coronavirus strategy, proved the inevitability of qualitatively new approaches to managing marketing activities of hotel and restaurant enterprises. These companies, unfortunately, rarely turn to scientific approaches, methods, marketing tools to reduce the level of crisis risk; practically do not implement important for their own successful development functions, such as digital monitoring of environmental factors, including audit of priority consumer needs, forecasting the post-coronavirus market, strategic trends in individual segments, etc. [199]. However, the growing level of competition and globalization, digitalization of activities have led to the introduction into practice of companies the latest marketing solutions. That is why the chosen direction is also relevant and timely.

Consideration of various scientific opinions has made it possible to understand that analysts consciously identify the reasons for the progressive recovery and further development of the market of hotel and restaurant services: the loss of the vast majority of firms dynamism in the global coronavirus economic crisis; the material component 
in the creation of a complex hotel and restaurant product is becoming less and less effective element of consumer value in the process of satisfying the basic interests of customers; marketing crisis of service production; loss of loyalty from regular customers. In general, the specifics of hotel and restaurant marketing are revealed in the works of scientists such as: Azar V., Durovich A., Karpova H., Kotler F., Mackenz D., Rozanova T., Saunders D., and others. Problems of regulating the development of marketing management systems of hotel and restaurant companies in a crisis are occasionally covered in the scientific works of famous scientists, namely: Zaitseva V., Kifyak V., Pavlyuk K., Porter M., Sklyar H., Harrod R., presentation of opinions which added a significant contribution to the classical knowledge of the issue. Practical aspects of marketing policy implementation in companies in this industry in the conditions of the COVID-19 pandemic are considered in the studies of A. Vindyk, S. Zhuravlyova, T. Kuklina, D. Mamotenko, V. Pruss, others. However, with a significant number of scientific ideas of domestic and foreign scientists today there are almost no comprehensive studies on the formation of approaches, tools, mechanisms for determining the marketing policy of consumers of complex products of hotel and restaurant companies, taking into account the realities of post-coronavirus business space . An important area of research is to study the conditions, specific features and feasibility of maintaining a segment of loyal consumers of hotel and restaurant product in the conditions of COVID-19 factors and based on the interests of the company and the client to develop post-coronavirus marketing policy.

It should be noted that the complex hotel and restaurant product is the end product of the micro-enterprise of the hotel and restaurant industry, which covers the processes of production, sales, organization of consumption in accordance with the theory of marketing services [200]. The concept of modern consumption of hotel and restaurant product is characterized by specific features: 1) complexity (goods, services, services); 2) short process of promotion (integration of production, sales and consumption); 3) continuous improvement of the customer service model; 4) innovative principles of sales; 5) mobile architecture of relations with consumers; 6) flexible dependence on modern development of branch and related technologies; 7) a 
high degree of dependence on the loyalty of a particular segment of customers [201]. The scheme of a complex hotel and restaurant product is presented in Fig. 5.4.3. It is clear that when positioning a hotel and restaurant product in the context of postcoronavirus development of the company's market should be studied in detail the updated needs of the segment of loyal customers, which, in turn, contributes to an effective strategy and marketing policy for their content. That is, the resumption of business activity and economic feasibility of the hotel and restaurant company on the market today directly depends on this segment.

\begin{tabular}{|c|c|c|}
\hline Hotel goods units & Hotel service units & Hotel additional service units \\
\hline$\vee$ & $\downarrow$ & $\vee$ \\
\hline $\begin{array}{l}\text { An integrated range of hotel } \\
\text { products }\end{array}$ & $\begin{array}{c}\text { An integrated range of hotel } \\
\text { services }\end{array}$ & $\begin{array}{l}\text { Integrated range of hotel } \\
\text { additional services }\end{array}$ \\
\hline$\downarrow$ & $\downarrow$ & $\downarrow$ \\
\hline \multicolumn{3}{|c|}{ Complex hotel product (hotel nomenclature) } \\
\hline \multicolumn{3}{|c|}{$\downarrow$} \\
\hline \multicolumn{3}{|c|}{ Complex hotel and restaurant product } \\
\hline \multicolumn{3}{|c|}{$\uparrow$} \\
\hline \multicolumn{3}{|c|}{ Complex restaurant product (restaurant nomenclature) } \\
\hline$\uparrow$ & $\uparrow$ & $\uparrow$ \\
\hline $\begin{array}{l}\text { An integrated range of } \\
\text { restaurant products }\end{array}$ & $\begin{array}{l}\text { An integrated range of } \\
\text { restaurant services }\end{array}$ & $\begin{array}{l}\text { An integrated range of } \\
\text { restaurant additional services }\end{array}$ \\
\hline$\uparrow$ & $\uparrow$ & $\uparrow$ \\
\hline Units of restaurant goods & Restaurant service units & Restaurant additional service \\
\hline
\end{tabular}

Figure 5.4.3. Scheme of a complex hotel and restaurant product

Recently, marketers have often made significant efforts to attract new customers, but this business policy is not always the most profitable [202]. In the context of the COVID-19 pandemic, domestic companies have found that attracting a new customer costs the hotel and restaurant company five to six times more than implementing the existing maintenance policy. Customer retention policy provides a set of marketing activities aimed at establishing a long-term, low-cost relationship between customers and the company for mutual benefit of both parties. Regarding the segment of loyal consumers, it is worth noting that they: 1) much longer prefer a particular institution; 
2) interested in buying a comprehensive hotel and restaurant product; 3) ready for partial self-service; 4) show resistance to small price fluctuations; 5) participate in product evaluation and promote the dissemination of information in the digital space.

In general, the definition of "loyal consumer" should be understood as a certain segment of the market of buyers of complex hotel and restaurant product, which chose the rational range of goods, services of hotel and restaurant company, formed the appropriate and justified by their own decisions and impressions has a stable positive emotional attitude to it, demonstrates the rejection of alternative competitors. From this position, the relevant criteria for the formation of loyalty to the consumer are: 1) giving preference to a particular hotel and restaurant product of a certain institution; 2) feeling of comfort when buying goods, services, service of the companies; 3 ) inclusion for a long time in the diversification of sales records on the treatment of other products and market offers from competitors; 4) the need for long-term use of a complex hotel and restaurant product; 5) acquiring a sense of satisfaction and desire to disseminate this information. Insanely, knowledge of the loyal customer's requests allows the company to influence its real and potential consumers, passing from the category of "dependent" on the market conditions to the category of the hotel and restaurant company, which regulates the product according to the customer's preferences.

It makes sense to distinguish the main benefits of retaining loyal consumers as a target market segment in the post-coronavirus perspective for the hotel and restaurant company: 1) effective marketing communication through the "consumer firm"; 2) the multiplicity of repeated purchases of various goods, services, services of the enterprise by one consumer; 3 ) the cost of creating a network of supporters and loyal customers partially reimburse the cost of developing a set of incentives and promotion systems for new customer groups (savings); 4) formation with their help of organizational culture of harmonious organization; 5) the use of the segment of loyal consumers as a tool to attract additional consumers and buyers of a complex product of the enterprise [203]. In turn, the basic requirements to the enterprise-manufacturer of a complex hotel and restaurant product from loyal consumers are: 1) constant modernization of product components; 2) creation of uniqueness and introduction of value system of 
consumption of hotel and restaurant product (image, quality, prestige, rationality, etc.); 3) providing up-to-date and complete information about new, updated, improved products, services, services of the company; 4) creation of digital space for the purpose of full-fledged communication of consumers of this segment in social networks, product evaluation, announcement of opinions; 5) providing opportunities for selfservice within the digital space of the firm.

The management of the hotel and restaurant company in the formation of postcoronavirus marketing policy to retain consumers should realize the priority of the following vectors: 1) a more favorable market model is monopolistic competition; 2) the consumer value of the product is the basis for maintaining the market segment of loyal customers; 3) consumer loyalty in a COVID-19 pandemic is a rather unstable criterion for assessing marketing policy; 4) the quality of goods, services, services of the firm is an important criterion for retaining the consumer and giving him the status of a supporter; 5) re-sale of the product to the target segment of consumers requires constant updating of the marketing complex.

The process of developing this policy should be preceded by an analysis of: 1) the presence of a sustainable segment of consumers of a complex hotel and restaurant product; 2) competitors with a market offer of an analogue product; 3 ) the volume of sales of a particular type of goods, services, services for a certain period; 4) innovative activity of competitors according to various criteria; 5) key success factors of the complex product (uniqueness, quality, image, price, technological level of customer service, digital service); 6) the stability of post-coronavirus forecast demand for certain units of goods, services, services of the enterprise.

The main purpose of the post-coronavirus policy of retaining loyal consumers of hotel and restaurant product is to establish long-term partnerships between producers and consumers on the basis of mutually beneficial interests of the parties. The basic objectives of this policy should be: 1) to ensure friendly relations between consumers, the company and business partners who supply related products and perform ancillary and service functions; 2) creation and proper support of modern digital space for digitalization of relations with the segment of loyal customers; 3 ) introduction of a 
transparent policy of communications and informing consumers about changes in the activities of the enterprise for the production of a comprehensive hotel and restaurant product; 4) encouraging consumers to take certain actions to realize the interests of the company; 5) involvement of customers in the process of dissemination of positive information about the product and the company; 6) formation of a favorable image and attractiveness of a complex hotel and restaurant product; 7) connecting customers to the "club" sales system.

To overcome obstacles to the implementation of post-coronavirus policy of retaining loyal consumers of hotel and restaurant product, the domestic company should completely reform the organizational structure of marketing and identify units that are functionally responsible for the market segment of loyal consumers [204]. In the post-coronavirus environment, only those hotel and restaurant companies that have gained experience in retaining this segment of customers during the period of COVID19 will be able to secure a stable position in customer relations. The functions of the company's marketing department must also change. Post-coronavirus areas of formation of a set of marketing functions for interaction with the segment of supporters of the company's product are presented in Table 5.4.6.

For effective interaction and management of a certain micro-segment of the loyal consumer market, it is necessary to: 1) know, study, analyze the facts related to a certain segment of consumers of complex hotel and restaurant product (regularly conduct retrospective analysis, establish the logic of events in this segment to establish effective interaction with clients, to introduce a mechanism for diagnosing problems in the process of satisfying their interests); 2) to predict the future goals of postcoronavirus development of the segment, and the goals and objectives should be the objects of constant monitoring and control, develop and update a strategic concept, action strategy aimed at realizing the potential of the innovative product to meet needs; 3) organize, provide, combine resources, sales technologies for their rational use in managing the development of the segment of loyal consumers; 
Table 5.4.6.

The directions for the formation of a set of marketing functions

\begin{tabular}{|c|c|}
\hline & Contents of a set of post-coronavirus marketing functions \\
\hline $\begin{array}{l}\text { Development of } \\
\text { post-coronavirus } \\
\text { marketing } \\
\text { strategies }\end{array}$ & $\begin{array}{l}\text { analysis of the strengths and weaknesses of the hotel and restaurant company; } \\
\text { monitoring the potential of the loyal customers segment; industry audit; } \\
\text { assessment of micro-segment potential; analysis of competitors; study of } \\
\text { relations with clients and partners; environmental impact assessment; } \\
\text { marketing audit; marketing audit of the internal environment; assessment of } \\
\text { ways to modernize the traditional and develop an innovative product; } \\
\text { development of a marketing plan; control of marketing activities }\end{array}$ \\
\hline $\begin{array}{l}\text { n of } \\
\text { aurant }\end{array}$ & $\begin{array}{l}\text { nalysis of trade flows; analysis of the effectiveness of sales channels; } \\
\text { nethods of stimulating demand; development of effective channels of } \\
\text { nteraction; specifics of conducting virtual demonstrations; organization of } \\
\text { ligital presentations; development of advertising policy }\end{array}$ \\
\hline $\begin{array}{l}\text { Post-coronavirus } \\
\text { segmentation of } \\
\text { the market of } \\
\text { loyal consumers }\end{array}$ & $\begin{array}{l}\text { ographical, demographic, psycho } \\
\text { oproaches to the division of market } \\
\text { egments; scientific synthesis of worl }\end{array}$ \\
\hline el & $\begin{array}{l}\text { rtain } \\
\text { arket } \\
\text { hess, } \\
\text { ons }\end{array}$ \\
\hline $\begin{array}{l}\text { Pricing for } \\
\text { and restau } \\
\text { services }\end{array}$ & $\begin{array}{l}\text { oyal } \\
\text { tors' } \\
\text { ount }\end{array}$ \\
\hline $\begin{array}{l}\text { Analysis of the } \\
\text { specifics of the } \\
\text { segment of loyal } \\
\text { consumers }\end{array}$ & $\begin{array}{l}\text { frequency } \\
\text { structure } \\
\text { in groups } \\
\text { cs on the }\end{array}$ \\
\hline & $\begin{array}{l}\text { search of foreign market segments of loyal customers; analysis of the } \\
\text { pediency of post-coronavirus retention of clients from the foreign market; } \\
\text { oviding opportunities for target groups to access digital services of the hotel } \\
\text { id restaurant company; large-scale digitalization of the company's } \\
\text { ternational business }\end{array}$ \\
\hline of & t-coronavirus policy of formatic \\
\hline $\begin{array}{l}\text { Improving the } \\
\text { technique of } \\
\text { marketing staff of } \\
\text { the company }\end{array}$ & $\begin{array}{l}\text { gnostics of the system of technological support of working conditions; } \\
\text { it of staff competencies; assessment of competencies; organization of } \\
\text { nings, seminars, webinars for employees of the marketing department; } \\
\text { entation of staff in the digital space }\end{array}$ \\
\hline $\begin{array}{l}\text { Organization of } \\
\text { effective } \\
\text { communication } \\
\text { policy }\end{array}$ & $\begin{array}{l}\text { ssessment of the level of digitalization of communication channels; } \\
\text { onducting effective marketing research of micro-segments of the market of } \\
\text { oyal consumers; introduction of innovative communication technologies; } \\
\text { xing feedback in digital space }\end{array}$ \\
\hline
\end{tabular}


4) create adequate marketing structures to ensure the implementation of strategic, tactical, operational goals for customer retention of the segment; 5) to provide coordination and integration of actions of divisions and experts who take part in creation of consumer value of a complex product.

Thus, the post-coronavirus policy of retaining loyal consumers of hotel and restaurant product: can be used as an effective tool for determining the economic development and directions of structural adjustment of the hotel and restaurant company with limited resources; help accelerate the transformation of economic and social systems, while helping to control changes in supply and demand; will help promote innovative ideas for the transformation of goods, services, services of the company through their perception by the segment of loyal consumers; should define a digital path for the possibility of adequate presentation of the hotel and restaurant product in the digital space; will create the potential for diversification of goods, services, services of the company, growth of their sales. Further research is promising in the direction of creating a favorable safe regional business space for tourism microenterprises.

\subsubsection{Directions and organizational and economic means of strengthening} the economic security of tourist micro-enterprises in the post-coronavirus period

Now, especially when the micro-business of the regional sphere of tourism operates in the conditions of COVID-19 factors, the idea of obligatory creation of a system of economic security at a certain enterprise is practically unquestionable. Today, both in the literature and in economic practice, there are different understandings of the system of economic security of the enterprise [205].

Tactics to ensure the security of a micro-enterprise involves the application of specific procedures and specific actions to ensure its economic security in the postcoronavirus business space of the region in tourism. Thus, we are talking about such procedures and actions as: expansion of the legal service of the enterprise (1); taking additional measures to preserve trade secrets (2); creation of a computer security unit 
(3); filing claims against the infringing counterparty (4); appeal to the courts (5); appeal to law enforcement agencies (6); digital security control in digital space (7), etc. Thus, a comprehensive system of economic security of the tourist micro-enterprise should include a structured certain amount of interdependent elements that ensure the security of the enterprise in achieving its main business goals. There is also an interdependence between strengthening the economic security of the tourism microenterprise sectors of certain regions of Ukraine and ensuring the national security of the state, including its components such as financial, social, innovation and technological, food, foreign economic, demographic, energy, environmental security, digital. In turn, the development of micro-entrepreneurship is a necessary prerequisite for socio-economic growth, democratization of society, increasing the level of digital transformation, ensuring the European vector of territorial development, modernization of infrastructure of locations, cities, districts, etc.

Priority areas for strengthening the economic security of tourism microentrepreneurship in the region should include: policy tools at the macro-level of the economic management hierarchy (1), and policy tools at the meso-level of the economic management hierarchy (2). In turn, it is expedient to include in the means of policy at the macro-level the hierarchy of economic management: first, strengthening of program-normative regulation of economic security of tourist activity of microenterprises; secondly, promoting the level of motivation of local governments to implement measures to strengthen the economic security of tourism. By means of policy at the meso-level hierarchy of economic management it makes sense to understand the activation of management functions of local authorities in the direction of creating a safe environment for tourism in a particular region. The structure of these management functions is presented in detail in Fig. 5.4.4.

Today, under the influence of COVID-19 factors, mainly the state and small and medium-sized local entrepreneurs contribute to tourism [206]. In addition, the transformational and systemic changes taking place in the economy of Ukraine, institutional transformations of the subject-object structure, as well as the digitalization of business and public authorities define the process of entrepreneurship as a 
phenomenon that becomes the foundation of post-coronavirus economy which under the creation of appropriate favorable conditions will have broad prospects for development (as evidenced by the experience of developed countries, in which indicators of development and the role of the micro-enterprise sector in the economy occupy a stable and important position), will ensure socio-economic growth of regions and countries.

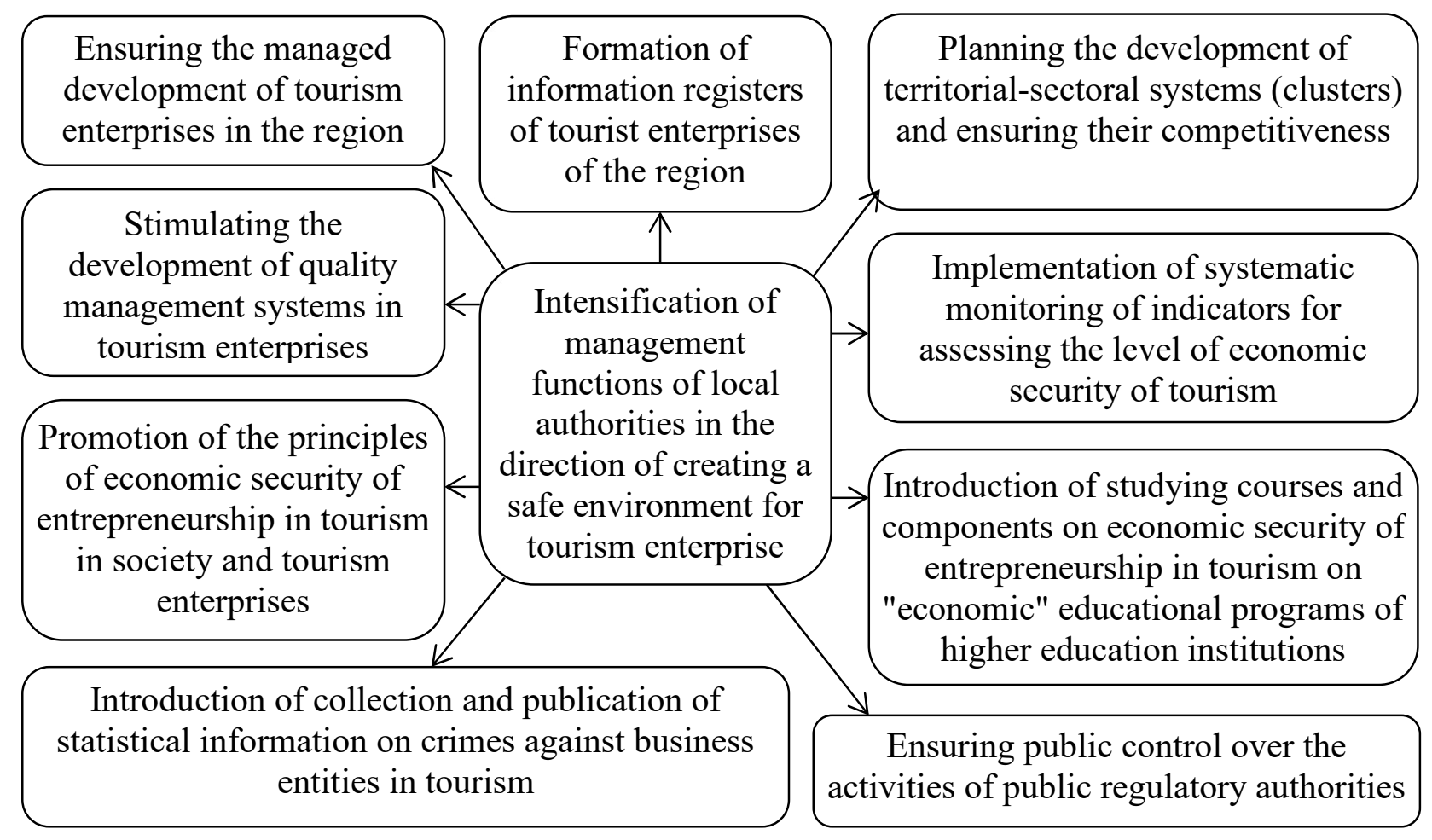

Figure 5.4.4. Activation of management functions of local authorities in the direction of creating a safe environment for tourism (structure)

It is expedient to emphasize that to these prerequisites the authors include: changes directly in the nature of the economic space and business relations, which are implemented within it (1); transformation on the latest post-coronavirus principles of economic principles of the system of social division of labor in the region (2); formation of the social stratum of owners, i.e. subjects of entrepreneurial (production, commercial) activity (3); legal protection of property rights, their inviolability and freedom to choose the sphere of transparent capital investment (4); variety of forms of product production, management structures, property in the multilevel economy of the region of the post-coronavirus period (5); openness of domestic markets and the 
national economy for the establishment of world economic relations (6); liberalization of economic processes (7). Thus, the strategic interests of public authorities in ensuring the economic security of micro-enterprises in tourism are directly determined by the desire to achieve social and economic development of the system, to form a democratic sphere of hospitality and ensure its development on European tourism principles. In this context, it is more important to outline the directions, goals, objectives and measures of public policy to ensure the strengthening of economic security of this sector of the regional economy [207].

When developing a strategy and a specific policy, according to the authors, it is necessary to identify a range of problems or factors of negative impact, which will be addressed by the developed measures. In addition to the negative impact of COVID19 factors, as well as existing preconditions and factors in the regions of Ukraine that hinder the development of micro-entrepreneurship and hinder market-reform transformations and post-coronavirus transformations, significant deterrents are also: credit system, tax policy, lack of favorable investment and investment climate. At the same time, the subjects of the tourism sector of micro-entrepreneurship do not have the opportunity in the regions to attract available financial and credit resources for entrepreneurial business for investment, innovation, modernization of production facilities. It remains a problem for the micro-enterprises of the region the home system of taxation that reduces business activity of population substantially, stipulates negative attitude of business-environment toward public government bodies. That is, the complex nature of these influences leads to the fact that the financial system of the country, which is a significant investment resource, prefers the speculative nature of circulation in the financial sector (capital accumulation), which almost does not pass into the real (production) sphere of the because the "last" level of profitability is much lower, and the payback period is longer.

According to this situation, it should be added that these conditions do not correspond to the nature of a favorable environment for doing business and until they are changed, the prospect of creating appropriate conditions for business development in the micro-enterprise sector in most regions of Ukraine is rather limited [208]. Also 
a problem for domestic tourism micro-enterprises and a characteristic feature of the modern business environment is the lack of an adequate civilized market for buying and selling businesses, which: significantly constrains investment activity (1); contributes to the illegal actions of certain "shadow" structures (2); leads to a decrease in the level of liquidity of domestic micro-enterprises (3); "freezing" of the funds invested in them (4); lack of incentives for owners to capitalize their own microenterprise and often to economically and organizationally unjustified creation (registration) of new legal entities, which, in turn, complicates the activities of registration, tax, law enforcement and other public bodies, creates a fictitious ballast of legal entities and eliminates reliability statistics on the increase in the number of microenterprises and their share in the tourism economy of the regions.

Given the systemic nature of these reasons, the solution of these problems is impossible due to the implementation of individual or a whole set of measures. Today it is necessary to develop and implement a strategy to change the relationship "government - tourism micro-business - society" on the basis of post-coronavirus phased implementation of a set of measures of regulatory, organizational, administrative, economic and law enforcement nature. The strategic goal of this set of measures, relevant decisions should be the need to form a viable competitive environment and favorable conditions for the development of legitimate business activities. It should be recognized that the public policy in the field of support for tourism micro-companies in the region is not systematic and coordinated and is not fully implemented to achieve its goals, which are set by public authorities. Therefore, the policy of supporting micro-entrepreneurship in Ukraine needs to be adjusted.

Based on the outlined trends, first of all it is necessary to ensure the recognition by regional socio-political groups of the ideology of obtaining less intensive, but longterm economic return from the limited resources invested. To do this, all socio-political groups should be aware of the connection between investing in less profitable areas of tourism (innovation, scientific and technological development, education, social sphere, etc.) and providing a qualitatively new and more efficient business space of the country and individual regions. It is expedient to develop and ensure public recognition 
of the fundamental priorities of post-coronavirus economic and tourist development of the region. First of all, it concerns the need to outline the basic principles of economic policy, which should be linked to the relevant system of moral values, form the basis for an effective model of tourism development in the region and micro-entrepreneurial environment and to ensure the elimination of existing contradictions, especially those that have a negative impact on the deepening of disintegration trends in the tourism environment. Among the priority principles it is expedient to fix: reduction of the distributive function of public administration bodies; ensuring the proportionality of economic and social growth; reducing the level of monopolization of the economy and its industries.

The main principles for ensuring the development of micro-entrepreneurship in the post-coronavirus economy of tourism in the region should be: emphasis on the development of tourism subsectors that have comparative and competitive advantages in the global economy of regional and global scale (1); high level of internal integration of the domestic tourism economy of the region, creation of a strong national tourism market as a fundamental basis for conquering and securing relevant niches in highly competitive and efficient global markets for integrated tourism goods and services (2); taking into account the different factor intensity of national tourism subsectors and industries, their capital and employment compared to other countries, taking into account the relevant domestic prices and their world counterparts (3); creation of a post-coronavirus system of incentives for public legitimization of shadow income from tourism activities and ownership of tourism infrastructure (4); ensuring investment in innovation, scientific and technological development, education and social sphere of regional tourism, which will ensure the development of these less profitable areas of tourism, including by amnesty "shadow" income from business activities invested in these areas (5).

In the post-coronavirus perspective, ensuring the liberalization of state economic policy by limiting the institution of public power, hypertrophied functions and financial levers of influence that allow easy manipulation of economic processes in tourism and make political activity an extremely attractive "business area" for various monopolistic 
associations and political and financial groups can be achieved through the following measures: a significant reduction in taxes while limiting the amount of other financial resources accumulated in the budget, the harmonization of customs tariffs and fees to the level required by the requirements of global business (1); elimination of "informal" benefits, preferences, subsidies paid from state and local budgets to large enterprises (2); significant simplification of the procedure for creating new micro-enterprises and liquidation of existing ones, passing of permitting and approval procedures (3); strengthening the antimonopoly legislation of Ukraine while increasing the role and increasing the weight and functions of the Antimonopoly Committee (4); judicial reform (strengthening the institutional support of the judicial system, increasing the openness and transparency of the judiciary, the introduction of the institute of case law in judicial practice) (5); separating power from micro-business by banning entrepreneurs from running for representative, executive or judicial positions until their business at the regional level is sold at an open auction with appropriate media coverage (6).

Based on the results of studying scientific works and research materials, which substantiate the strategic interests of public administration bodies in the field of national and regional economic security in tourism, the following approaches are considered: approaches to establishing a permanent system of economic security monitoring of microenterprise sector at different levels of public administration (1); measures aimed at strengthening the competitive position of the subjects of this sector of the economy, as well as the search for organizational and economic mechanisms to strengthen the economic security of microenterprises and individual micro-businesses in the region (2): functions to ensure economic and social security growth and competitiveness and a number of requirements for the system of public management of micro-entrepreneurship in the region. Based on the study of scientific opinions and experience of public authority in tourist regions and the function of regulating the development of micro-entrepreneurship, the main requirements are presented, which, according to the authors, are determined by the concept of economic security of microentrepreneurship in tourism (Fig. 5.4.5). 


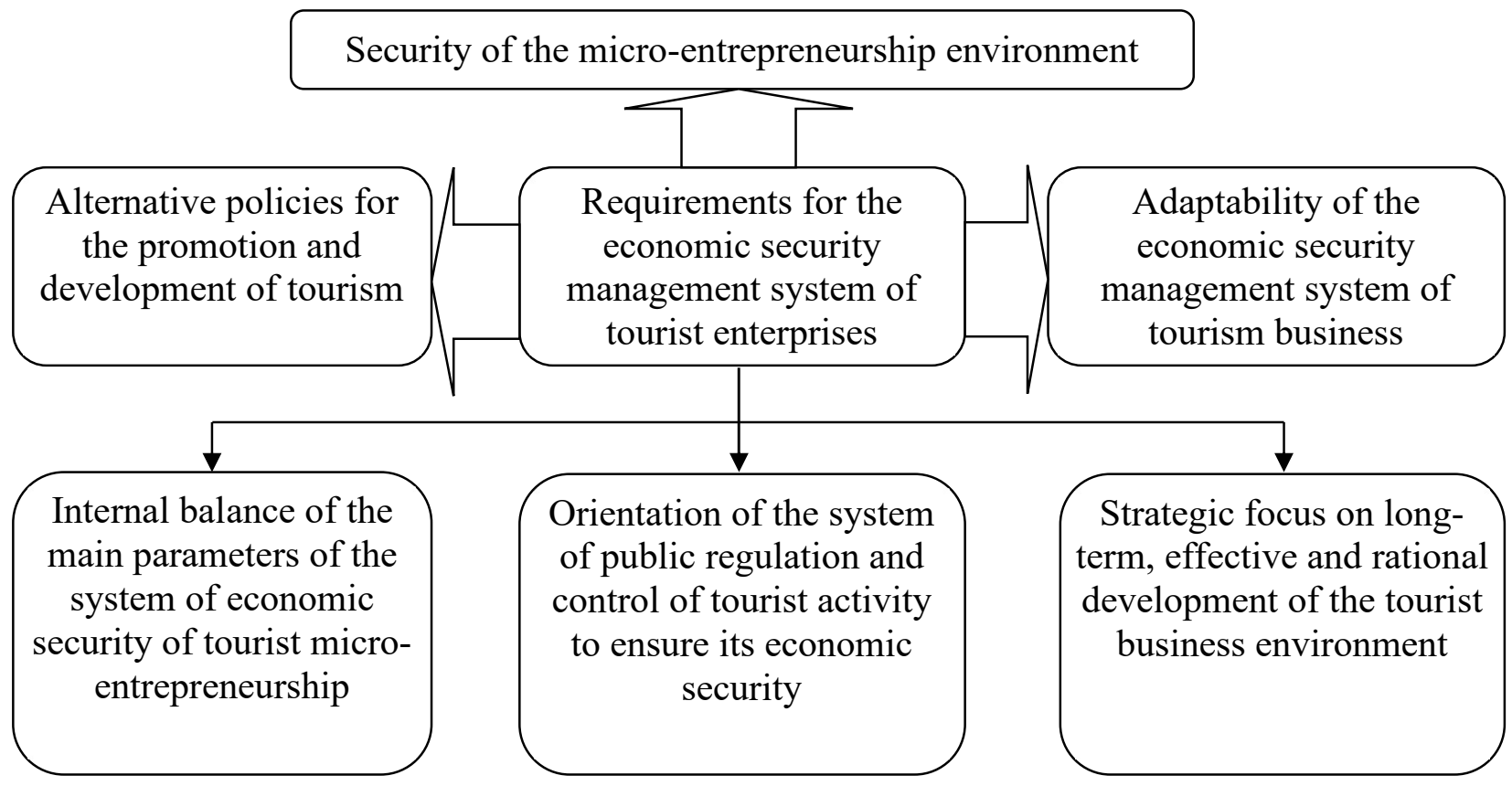

Figure 5.4.5. Requirements for effective public policy in ensuring the economic security of tourism micro-enterprises

From this point of view, the orientation of the system of public regulation of tourism in the regional sector of micro-entrepreneurship to ensure its economic security implies that management decisions made in any area of public regulation of the economy and have an impact on micro-entrepreneurship must be considered and evaluated in terms of their impact on the economic security of the micro-enterprise sector, both during the effects of the COVID-19 pandemic and in the post-coronavirus perspective. Implementation of the requirement of alternative management decisions implies that the preparation of a specific regulatory act or decision within the system of public regulation of micro-entrepreneurship should take into account options for influencing the possible development of tourism enterprises in the region, structure and key indicators of economic security [209]. The requirement of adaptability of the economic security management system of tourist micro-enterprises means that this system must take into account the current state and future post-coronavirus changes in the resource provision of the micro-entrepreneurial environment, environmental factors, regional economic structure, competitiveness and financial stability of microenterprises and other parameters of transformation.

The strategic orientation in the management of economic security of the tourist 
micro-enterprise of the region on long-term and rational sustainable development obliges public administration to make management decisions taking into account not only the set of external and internal business environment, but also measures to protect the interests of tourism. Under the conditions of realization of target complex programs of economic safety of tourist microenterprises of the region it is possible to reduce risks and a threshold of their economic safety by means of external factors: target projects. When drafting the target program for the development of the domestic tourist region for the post-coronavirus perspective, the following areas should be covered: recreational and tourist nature management of the region, protection and restoration of recreational and tourist resources (1); economic development of territories, change of proportions in placement of productive forces, clustering of non-mass forms of tourism, formation of recreational and tourist system on the basis of modern infrastructure (2); financing of projected activities (3); improving the system of legal support for the management of micro-entrepreneurship (4).

At the same time, as directions and tasks of formation of a competitive regional tourist product within the framework of the target program of development of recreational and tourist region, it is expedient to allocate the following: in the direction of "providing conditions for the development of recreation and tourism by local governments": the creation of a coordination council at the local administration to perform coordination functions and conduct business operations, implementation of decision-making procedures in recreational and tourist activities in a municipality (1); within the direction of "regional management of recreational and tourist sphere": creation of new institutes of tourism management and restructuring of existing in accordance with the goals and objectives of recreation and tourism in the region (2); within the direction of "modern marketing strategy for the promotion of recreational and tourist product in the domestic and international markets": development of a calendar of events taking place in the region; expansion of the sales network; joint promotion of a regional recreational and tourist product, development of international cooperation; formation of the image of the region (3); within the direction of "formation of the legal framework for the development of recreation and tourism": 
definition of legal documents to be adopted at the regional level and development of recommendations for the adoption of national documents or change their provisions to improve the efficiency of recreational tourism (4); within the direction of "financial support for the development of recreation and tourism": search for sources of funding for the development of recreational and tourist sphere and compiling a list of possible recipients of resources and structures to decide on the provision of funds to microenterprises (5); within the direction of "staffing the development of recreation and tourism": ensuring cooperation between micro-enterprises and educational institutions to improve the quality of education and better consideration of market requirements in training professionals and entrepreneurs, organization of branches of educational institutions, courses for residents of recreational and tourist areas local employment; development of a system of interaction with employment services of different levels (6); within the direction of "accounting for environmental, political and other risks": development of measures to reduce natural risks in recreational and tourist activities, their compensation; formation of a special program of natural risk management in recreational and tourist regions; development of measures for operational crisis management (7); within the direction of "formation of conditions for the development of recreation and tourism within specially protected natural areas": initiation of projects to create specially protected natural areas of regional and local importance; promoting the investment attractiveness of infrastructure in specially protected natural areas; development of norms of recreational and tourist loads for different types of specially protected natural territories, destinations and locations of the region; formation of bases of the organization of natural parks in a zone of establishments of a resort and sanatorium profile for the purpose of preservation of a recreational and tourist resource (8).

In general, strategic preparation for post-coronavirus economic conditions at the level of a separate domestic tourist region, destination, location requires not only the definition of directions and organizational and economic means of strengthening economic security of tourist microenterprises, but also procedures for developing and implementing a comprehensive balanced system of socio-economic, legal and 
administrative and managerial nature, which aims to create conditions for the development of a qualitatively new level of tourism potential and ensure the formation of sustainable competitive advantages of tourism micro-entrepreneurship in a particular area while ensuring stable diversified employment and opportunities to participate in projects by business structures. Thus, the post-coronavirus formation of the tourist micro-business of the region on the basis of economic security in Ukraine, as a condition of guaranteeing the sustainable development of the tourist destination, region, location in the global post-coronavirus world is only possible due to the synergy of interests and needs of all participants. In particular, investors must be confident in return on investment, as tourism innovation ideas have a significant degree of risk, which is caused by the high capital intensity of infrastructure projects for the tourism business and too long payback periods with an unknown end result. Therefore, along with the development of infrastructure, public authorities must share the risks of private investors and provide long-term post-coronary guarantees of fulfillment of obligations: favorable lease of land, tax benefits, long-term loans at low interest rates, opportunities to attract foreign personnel. Further scientific interest is required to investigate the activation of tourism micro-business forces in the region in the direction of full-cycle digitalization of processes through the use of the leading experience of professionals and companies. 